\title{
Water Resources in the
}

\section{Future:}

\section{Problems and Solutions}

\author{
JOSÉ GALIZIA TUNDISI
}

\section{Introduction: the main causes of the water "crisis"}

ccording to some specialists, the water crisis in the 21 st century is
much more related to management than to a real crisis of scarcity and
stress (Rogers et al.,2006). Nevertheless, according to other specialists, it is the result of a set of environmental problems aggravated by economic and social development problems (Gleick, 2000). Somlyody \& Varis (2006) maintain that the deepening and complexity of the water crisis are due to real problems of availability and increased demand, and to a sectoral management process that responds to problems without a systematic approach that tries to foresee them. Tundisi \& Matsumura-Tundisi (2008) accentuate the need for a systematic, integrated and predictive approach to water management at a level decentralized to the river basin. According to these authors, a consolidated data base transformed into a management tool can be one of the most effective forms of confronting the problem of water scarcity, water stress and deteriorating quality.

Tundisi et al. (2008) highlight that, in the broad social, economic and environmental context of the 21 st century, the following principal problems and processes are the main causes of the "water crisis":

- Intense urbanization, increasing the demand for water, expanding the discharge of contaminated water resources, while there is tremendous demand for water for drinking and economic and social development (Tucci, 2008).

- Water stress and scarcity in many regions of the planet due to alterations in availability and increased demand.

- Poor infrastructure or infrastructure in a critical state in many urban areas, with losses in the network of up to $30 \%$ after treatment.

- Problems of stress and scarcity due to global changes with extreme hydrological events increasing the human population's vulnerability and compromising food security (intense rains and intense periods of drought). 
- Problems caused by the lack of articulation and lack of consistent actions of governability of water resources and for environmental sustainability.

This set of problems has local, regional, continental and planetary dimensions. These problems contribute to:

- An increase and exacerbation of sources of contamination.

- Alterations of the sources of water resources - with scarcity and decreased availability.

- Increased vulnerability of the human population due to contamination and difficulty of access to good quality water (potable and treated).

- This set of problems is related to the quality and quantity of water and the response to these causes interferes in human and public health, with a deterioration of the quality of life and of economic and social development. The central position of water in the generation of energy, food production, sustainability of biodiversity and global changes is highlighted in Figure 1.

Figure 2 presents the principal inter-relations of the processes that affect the quality and quantity of water, the aquatic biota and the human population.

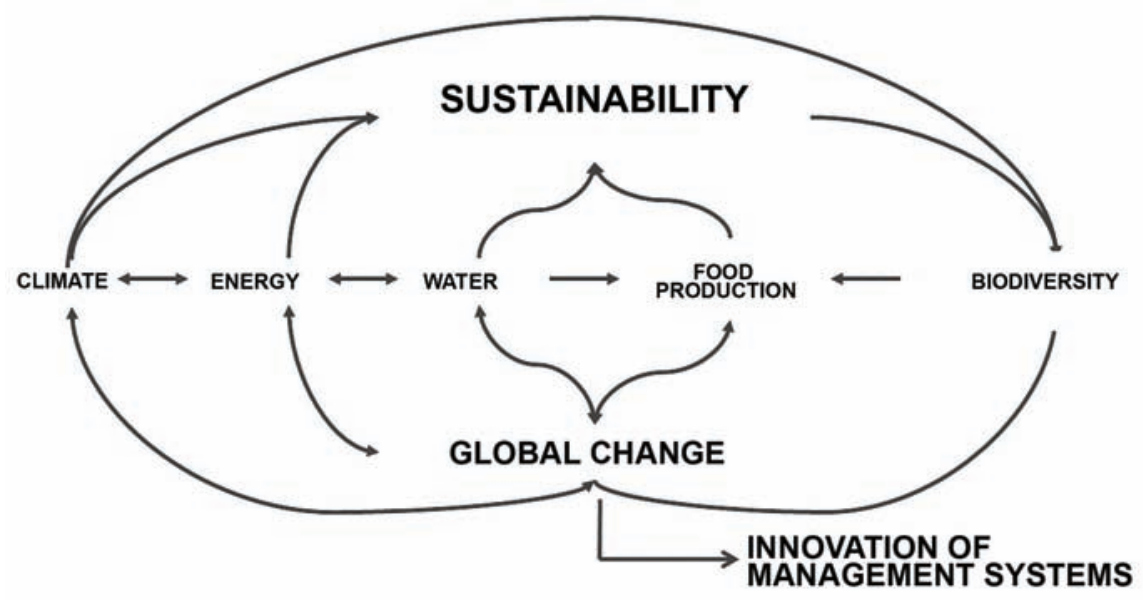

MATRIX OF COMPONENTS AND INTERACTIONS

Figure 1

Water and its central position in relation to processes such as biodiveristy, energy and climate.

\section{Methodologies and proposals for solutions and priorities}

Considering this situation, what approaches, programs and projects can promote a profound alteration in water management and in the preparation and application of creative solutions of suitable cost? 
Initially, it should be considered that an economic evaluation of water resources "services" and of aquatic ecosystems should be considered to be an important foundation for the methodology and future actions. These "services" and the determination of their economic value will be the basis for the proper governability of hydric resources.

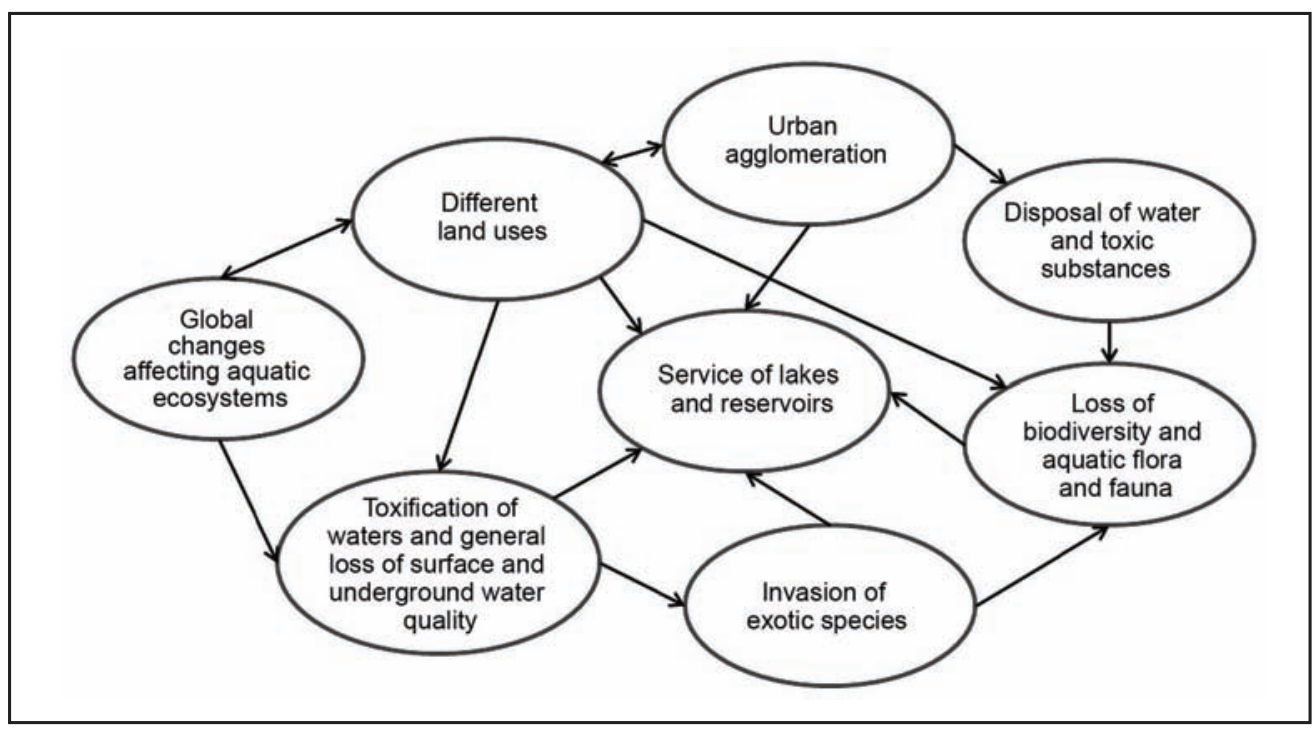

Figure 2 - Main global problems affecting services of aquatic ecosystems and availability of water and the quality of surface and underground waters.

Services such as regulation of cycles, climate control, water supply, energy and food production should be the basis for a new approach in the management and governance of water resources (MEA , 2003). Advanced monitoring capacity with the preparation of a data base and the production of software suitable to the management is another methodology of broad applied scope. In addition, managers should have advanced training in the following sense: integrated, predictive management at the level of the river basin is what should be the basis of this training.

Concerning the governance of water, the decentralizing movement that exists promoting management at the watershed level is essential. The hydrographic basin - a biogeophysiographic unit - that drains into a river, lake or ocean, is the natural unit of research and management (Likens, 1992; Tundisi, 2003; Tundisi \& Matsumura-Tundisi, 2008). A hydrographic basin has all the elements for integration of biogeophysical, economic and social processes. It is the natural unit that allows institutional integration, integration and articulation of research with management and also allows establishing a data base that can function as a platform for the development of projects with alternatives, considering their costs. It is increasingly evident that new ecotechnologies and eco-hydrologies that offer solutions that include the uses of natural systems and natural processes will be intensively utilized in the conservation and recovery of 
lakes, reservoirs and rivers and in the conservation of underground water and maintenance of aquifers (Zalewski, 2007).

In addition to the problem of governance of water resources, another element of management should also undergo significant change: from the current local, sectoral and response management there is now a transition to management at the level of the ecosystem (watershed) that is integrated (integrating the cycle of atmospheric, superficial and underground waters and integrating the multiples uses).

The participation of users, the public, the private sector and the public sector should be one of the principal focuses of this governance of water resources in the context of watersheds (Rogers, 2006). This participation should improve and deepen the sustainability of the supply and demand and of the collective security of the population in relation to availability and vulnerability.

\section{Water in agriculture}

Global demand for food production increases progressively at very high rates. Currently, in most countries, continents and regions, agriculture consumes nearly $70 \%$ of the total available. There is an enormous need for reduction of this use through the introduction of appropriate technologies, the elimination of waste and introduction of reuse and recycling. The uses of water include excessive utilization for irrigation from underground waters. According to Llamas \& Martinez Santos (2006), the intensive use of underground water for agriculture in arid and semi-arid countries and regions has provoked a drastic decrease in the volume of the aquifers, increasing the costs of water extraction $(0.01 \mathrm{US} \$ / \mathrm{m} 3$ or up to $0.2 \mathrm{US} \$ / \mathrm{m} 3$ ) and increasing the cost of irrigation per hectare (which oscillates from US $\$ 20$ - US $\$ 1,000$ per hectare, depending on the quality of pumping). Investment in more profitable food production - cash crops - means greater investment and more intensive uses of water in agriculture. The degradation in the quality of surface and underground water is another important component of use of water for agriculture, and this degradation should be quantified. The eutrophication of lakes, reservoirs and rivers is one of the consequences of the excessive use of fertilizers in agriculture, which combined with alterations in drainage, can considerably and quickly increase this problem, even in underground waters. The evaluation of virtual water (used in agriculture), the development of technologies to eliminate waste and improve performance in irrigation and; the introduction of the reuse of water in agriculture are some of the urgently needed solutions in this area.

\section{Water and regional and national economies}

Regional and national economies depend on the adequate availability of water for the generation of energy, public drinking supplies, irrigation and food production (agriculture, aquiculture and fishing for example). Improving the managment of water resources integrating and improving the multiple uses, 
flexibly allocating water to different users and investing in public sanitation (sewage collection, resolving sanitary problems of waterborne diseases) is one of the most important forms of economic and social development, because improving the quality of life promotes the generation of jobs and income and expands the ability to supply water for multiple uses and stimulates the economy (Bhatia \& Bhatia, 2006).

Low cost technologies can support the implantation of measures and the development of actions in basic sanitation, especially for low income populations on the periphery of large metropolitan regions (Tundisi et al., 2006).

\section{Water and climate change}

Climate change will have an important role in the hydrological cycle and in the quantity and quality of water. These alterations can promote countless changes in the availability of water and in the health of the human population. With various alterations in continents and regions, three fundamental problems should be studied to promote solutions: a) hydrological extremes - hydrological extremes that will occur in different continents and regions should affect human populations due to disasters (floods, mudslides, overflows) or intense droughts (increase in semi-arid and arid regions), compromising human health, food security and increasing the vulnerability of the cycles and biogeochemical processes;

urban areas can be extremely affected by these hydrological extremes; b) contamination - studies undertaken in many regions indicate a sharp increase of contamination aggravated by salinization and decontrol of land use, interfering with the cycles of phosphorus, nitrogen and heavy metals (Martineli et al., 1999) - the eutrophication of surface waters (rivers, lakes and reservoirs) should increase because of higher water temperatures and thermal resistance to circulation: as a consequence there will be greater frequency of outbreaks of cyanobacterium (Paerl \& Hussmann, 2008), aggravating the toxicity of springs and natural water supply sources; c) water and regional and national economies. These hydrological extremes and the increased contamination will effect regional economies, causing profound alterations in the economy dependent on the availability and demand for water resources.

The solution to confronting the consequences of the effects of global changes in water resources is to adapt to these alterations by promoting better governance at the watershed level, developing advanced technologies for monitoring and management while expanding community participation users and the public in general - in this management and in the sharing of the technological processes that will improve the infrastructure of the database to give greater sustainability to the actions.

\section{Water resources and international cooperation}

Due to the climatic changes, the evidence of which has been quite clear since the end of the 20th century and the beginning of this 21 st century 
(IPCC, 2007), there is a need for intense international cooperation, especially in watersheds shared by various countries. The development of these international partnerships in watershed management has been the object of discussions, analyses, proposals and some actions that seek to share problems, diagnose the causes and promote joint solutions (Tundisi, 2003; Somlyody \& Varis, 2006).

In South America, effective international cooperation has developed in the Plata Basin (shared by Argentina, Brazil, Chile, Paraguay and Uruguay) and in the Amazon basin (shared by nine countries). Joint monitoring actions to control water quality, joint studies to evaluate the impact of land use on contamination and degradation of water resources and joint training programs for water resources managers are some actions and activities already undertaken that have stimulated long term public policies for the management of these watersheds.

Other important examples in which international cooperation has acted intensively to resolve common problems of availability, demand and scarcity are:

- International cooperation programs in the ten countries that share the Nile River basin (Magadza, 2002), which, with a population of approximately 230 million, have growing needs for uses and the demand of waters and large problems of sanitation (population growth of $3.9 \%$ a year).

- International cooperation for management of the Caspian Sea shared by five countries. One of the main problems is the exploration of petroleum and the potential for contamination in this region, in addition to fishing production that is economically important (Golubev, 2002).

- International cooperation in the Danube River watershed shared by 10 countries. The main problems include: navigation and transportation, water uses, pollution control and environmental protection of the Danube River and its 300 tributaries (Jansky, 2002)).

Currently, 150 international accords related to trans-border watersheds are underway, in Europe and the United States.

One considerable advance in the shared management of water resources in Europe is the European Framework Directive (Jansky, 2002). Its guidelines have the following objectives:

- To provide higher quality water for human consumption.

- Make better quality water available in rivers and lakes for public use in recreation (bathing and swimming).

- Reduce water pollution as part of the local and regional inheritance and part of environmental actions towards sustainability.

Another important initiative is the action proposed by the InterAcademy Panel (IAP), which joins 96 Science Academies, to expand and deepen the 
education and abilities of water resources managers to instill an integrated and systematic vision. Currently, six countries already promote regional seminars, courses and publications in a joint effort to form an international network: South Africa, Brazil, China, Russia, Poland and Jordan. In addition to this effort, Science Academies from the Americas grouped in an international association, the InterAmerican Network of Academies of Sciences (Ianas), is promoting courses, discussions, seminars and the implementation of a guidebook for each country with diagnoses, prognostics and management strategies for water in the countries of the Americas (Tundisi \& Scheuenstuhl, 2008, to be published).

\section{Water resources and energy}

Energy production, especially in Brazil, depends on the availability of water resources, given that $50 \%$ of the Brazilian energy matrix depends on this resource. In addition, the transportation of treated water depends on energy for pumping, which increases the cost to make it available. In the case of Brazil and other countries dependent on hydroelectric energy, long term strategic studies should set the bases for this future exploration, as well as examine the consequences of this exploration on the hydrographic basins and on the hydrosocial cycle.

\section{Water resources in Brazil: priorities for governance, conservation and recuperation}

Although Brazil has $14 \%$ of the planet's water, there is an unequal distribution of the volume and availability of water resources: while a resident of the Amazon has 700,000 m3

of available water per year, a resident of the São Paulo metropolitan region has $280 \mathrm{~m} 3$. This disparity brings countless economic and social problems, especially considering availability and demand and human health in the periphery of Brazil's large metropolitan regions. Therefore, basic sanitation, sewage treatment, recuperation of infrastructure and of water sources are essential priorities. Another priority is to advance in the management of water resources with the consolidation of decentralization and governability through management at the level of the watershed. In this case, the interaction between water resources availability and demand with the population of the watershed and the economic and social activity, considering the hydrosocial cycle is also essential and of great importance for the future.

The great availability of water in certain regions of Brazil should be considered, without a doubt, an enormous natural resource to be used for regional economic development, for economic stimulus and for the promotion of appropriate development alternatives, based on the hydrosocial cycle.

The revitalization of rivers, lakes and reservoirs in many regions of Brazil, especially the Southeast, can also promote economic stimuli and recovery of the hydrosocial cycle. In these impacted regions of the Southeast with very 
high environmental liabilities, the revitalization can promote the generation of employment and income, new opportunities for multiple uses and generate an industry of new and promising management technologies (advanced monitoring, consulting, human resource training).

It is essential, however, to promote nationally in Brazil, a set of strategic studies of water resources and energy, water resources and the economy, water and human health and water and global changes, in order to promote long term visions and scenarios that stimulate consolidated public policies.

The important role of desalinization for providing water to coastal cities should also be considered and even in salty lakes in the interior of the Northeast, to make more water available to the population. This is one of the solutions that can become viable once the technology makes the cost of desalinization more accessible.

Concerning transposition, and specifically the transposition of the São

Francisco River, it is important to consider that only a joint project for river revitalization (and de-polluting) and a large regional development project) can be the basis for the transposition (Tundisi et al., 2008).

\section{Conclusions}

An approach based on management, research and preparation of a data base at the level of the hydrographic basin must consider the value of the "services" of the aquatic ecosystems and of the hydric resources, a predictive capacity based on a dense and technically advanced monitoring program and a suitable system of water governance designed to promote opportunities for regional and sustainable development based on the water available and the demand. Integrated, predictive management with alternatives for and improvement of the multiple uses must be implanted at the level of hydrographic basins in order to decentralize management and provide opportunities for participation to users and the public and private sectors. Education of all levels of the community and the preparation of managers with new approaches is another necessary development for water resources management in the 21 st century.

\section{Bibliographic references}

BHATIA, R.; BATHIA, M. Water and poverty alleviation: the role of investments and policy interventions. In: ROGERS, P. P. et al. (Ed.) Water crisis: myth or reality? London: Fundación Marcelino Botín, Taylor \& Francis, 2006. p.197-220.

GLEICK, P. H. The world's water. 2000-2001. Report on Freshwater Resources. Island Press, 2000. 315p.

GOLUBEV, G. N. The Caspian as an international water system. In: JANSHY, L. et al. (Ed.) Lakes and reservoirs as international water systems: towards world lake vision. UNU, 2002. p.45-54. 
IPCC. Climate Change 2007: Impacts, Adaptation and Vulnerability. Working Group II Contribution on the Intergovernmental Panel on Climate Change. Fourth Assessment Report. Summary for Policymakers. 2007. 22 p.

JANSKY, L. River Danube: needs for integrated river management. In: JANSHY, L. et al. (Ed.) Lakes and reservoirs as international water systems: towards world lake vision. UNU, 2002. p.55-68.

JANSKY, L. et al. Lakes and reservoirs as international water systems. United Nations University, 2002. 110p.

LIKENS, G. E. The ecosystem approach: its use and abuse. Oldenhorf / Luhe: Ecology Institute, Oldendorf / Luke, Germany, 1992. 166p.

LLAMAS, M. R.; MARTINEZ SANTOS, P. Significance of the silent revolution of intensive groundwaters use in world water policy. In: ROGERS, P. P.; LLAMAS, M. R.; MARTINEZ CORTINA, M. (Ed.). Water crisis: myth or reality? Espain: Fundación Marcelino Botín, Taylor \& Francis, 2006. p.163-80.

MAGADZA, C. H. D. Emerging issues in sustainable water resources management in Africa. In: JANSKY, L. et al. (Ed.) Lakes and reservoirs as international lake systems. Towards World Lake Vision. UNU, 2002. p.14-27.

MARTINELLI, L. A. et al. Effects of Sewage on the Chemical Composition of the Piracicaba River, Brazil. Water, Air and Soil Pollution 110, 1999. p.67-79.

MILLENIUM ECOSYSTEM ASSESSMENT (MEA). Ecosystems and Human Well Being: a framework for assessment. Island Press, 2003. 245p.

PAERL, H. W.; HUSSMANN, J. Blooms like it hot. Science, v.320, p.57-8, 2008.

ROGERS, P. P. Water governance, water security and water sustainability. In: ROGERS, P. P. et al. (Ed.) Water crisis: myth or reality? London: Fundación Marcelino Botín, Taylor \& Francis, 2006. p.3-36.

ROGERS, P. P. et al. (Ed.) Water crisis: myth or reality? London: Fundación Marcelino Botín, Taylor \& Francis, 2006. 33lp.

SOMLYODY, L; VARIS, O. Freshwater under pressure. International Review for Environmental Strategies, v.6, n.2, p.181-204, 2006.

TUCCI, C. E. M. Águas urbanas. Estudos avançados, v.22, n.63, p.1-16, 2008.

TUNDISI, J. G. Água no século 21: enfrentando a escassez. RIMA/IIE, 2003. 247p.

Bridging water research, innovation and management: enhancing global water management capacity. In: PROCEEDINGS OF THE VI REGIONAL WORKSHOP Water Resources and Water use Problems in Central Asia and Caucasus. IAP, IWEP, Russian Academy of Sciences, 2008, p.86-94.

TUNDISI, J. G.; MATSUMURA-TUNDISI, T. Limnologia. São Paulo: oficina de textos, 2008. 631p.

TUNDISI, J. G.; SCHEUENSTUHL, M. (Ed.) Bridging water research and management: new perspectives for the americas. IIE, IIBRH, Ianas, Brazilian academy of sciences, IAP, 2008. (No prelo).

TUNDISI, J. G. et al. Reservatórios da Região Metropolitana de São Paulo: conseqüências e impactos da eutrofização e perspectivas para o gerenciamento e recuperação. In: TUNDISI, J. G.; MATSUMURA-TUNDISI, T.; SIDAGIS GALLI, 
C. (Ed.). Eutrofização na América do Sul: causas, conseqüências e tecnologias de gerenciamento e controle. IIE, IIEGA, ABC, IAP, Ianas, 2006. p.161-82.

TUNDISI, J. G. et al. Conservação e uso sustentável de recursos hídricos. In:

BARBOSA, F. A. (Org.) Ângulos da água: desafios da integração. Belo Horizonte: Editora UFMG, 2008. p.157-83.

ZALEWSKI, M. Ecohydrology in the face of the Anthropocene. Ecohydrology and Hydrobiology, v.7, n.2, p.99-100, 2007.

ABSTRACT - The present water crisis has many components of an environmental, economic and social origin: overuses of water, pollution, changes in availability, and water mismanagement are some of the current problems. To cope with these problems and enhance strategies for long term management, the following programs and approaches are presented: a) A watershed approach, integrating research, monitoring, data base and management; b) An improved water governance system based on participation of stakeholders and the public and private sector; c) Strategic studies considering water and the economy, water and metropolitan regions, water and energy; d) A framework for international cooperation on shared watersheds; e) An economic evaluation of water resources services (surface and underground, lakes, rivers and reservoirs). f) A capacity building program for managers, with an integrated, predictive and hydrographic basin approach.

KEYWORDS: Water resources, Planning, Management, Sustainability, Future actions.

José Galizia Tundisi is president and researcher at Instituto Internacional de Ecologia, São Carlos-SP. @ - tundisi@iie.com.br

Received on 7.7.2008 and accepted on 7.8.2008.

Translated by Jeffrey Hoff. The original in Portuguese is available at http://www.scielo. br/scielo.php?script=sci_issuetoc\&pid=0103-401420080002\&lng=pt\&nrm=iso. 